\title{
THE STATUTE OF FRAUDS AND THE BUSINESS COMMUNITY: A RE-APPRAISAL IN LIGHT OF PREVAILING PRACTICES
}

THE controversial Statute of Frauds, currently in effect in most American jurisdictions, provides that agreements for the sale of goods will be enforceable only against a party who has signed a written memorandum of the transaction. ${ }^{1}$ Commentators have criticized the Statute on the grounds that it does not reflect actual practice in the business community and serves as an instrument rather than a preventive of fraud, since it is invoked only to enable a party to renege on an oral business deal which he was reasonably expected to honor. ${ }^{2}$ It is further argued that the Statute's conclusive presumption of invalidity serves no useful purpose, since modern fact-finding techniques will allow the triers of fact to ascertain accurately the existence or absence of an

1. The American legislation derives from $\S 17$ of the Statute for the Prevention of Frauds and Perjuries, 1677, 29 Car. 2, c. 3. Modified forms of this section appear in thirty-three states and the District of Columbia as $\$ 4$ of the UnIform SAles ACT; in Pennsylvania, as $\$ 2-201$ of the UNIForM CoMsmercial Code; and in seven states, as separate legislation: FLA. Stat. Ann. \$ 725.02 (Supp. 1956); Ga. Code Ann. \$ 20-401 (Supp. 1955) ; Mrss. Cone Ann. $\$ 268$ (1956) ; Mo. Rev. Stat. $\$ 432.020$ (Supp. 1956); Mont. Rev. Codes ANn. $\$ \S 13-606,74-201$ (1955) ; OkzLa. Stat. $\$ 15-136$ (Supp. 1956); S.C. CoDE $\S 11-103$ (Supp. 1956). In New Mexico it is part of the common law. See Childers v. Talbott, 4 N.M. 168, 16 Pac. 275 (1888). The remaining six states (Kansas, Louisiana, North Carolina, Texas, Virginia and West Virginia) have no specific limitations on the enforceability of oral agreements for the sale of goods.

Section 17 of the original Statute of Frauds was only one of twenty-five sections which barred enforcement of various types of oral agreements. Many American jurisdictions have also adopted some of the other sections, and all such legislation is commonly groupsd together under the heading of the Statute of Frauds. See REstatenrent, Contracts $\$ \$ 178-225$ (1932). This Comment is limited in scope to a discussion of Section 17 and its successors; thus all references to the Statute of Frauds (hereinafter sometimes called the Statute) are only to those provisions which deal with the enforceability of oral agreements for the sale of goods.

It should be noted that the Statute only requires a signed memorandum from the party to be charged. See UNIForM SALEs AcT $\S 4(1)$. Thus, a party to a transaction who has not himself signed, and whose promise is thus unenforceable, can nevertheless enforce the signed promise of the other party. 2 CoRBIN, CONTRACTs $\$ 282$ (1950). In addition, the requirement of a "signed" memorandum is not a literal one. A printed or stamped name which reasonably identifies the promisor is sufficient. See Restatenrent, Contracts $\S 207$ (a), illustration 2 (1932). Moreover, some oral promises for the sale of goods may be binding notwithstanding the Statute. For discussion of some of the exceptions to the operation of the Statute, see note 9 infra; note 43 infra and accompanying text; UNIFORM SAles ACT $\$ 4(1)$ - (3); UnIFora Comimercial Code $\$ 2-201$.

2. See, e.g., Corbin, The Uniform Commercial Code-Sales; Should It Be Enactedi, 59 Yale L.J. 821, 829-34 (1950); Stephen \& Pollock, Section Sevcntcen of the Statute of Frauds, 1 L.Q. REv. 1, 5-7 (1885) ; Willis, The Statute of Frands-A Legal Anachronism, 3 IND. L.J. 427, 528, 540-42 (1928); 13 CORNELL L.Q. 303 (1928). 
agreement. ${ }^{3}$ On the other hand, the Statute is not without defenders. They assert that it represents contemporary business practice, which is partly a product of the normative effect of the Statute; that the observance of written formalities is a healthy procedure tending to eliminate uncertainty in business transactions; and that the Statute encourages such procedure by rewarding businessmen who insist upon adherence to the formalities. ${ }^{4}$

Although the conflicting evaluations of the Statute of Frauds are chiefly attributable to different basic assumptions concerning business practice, writers have made little attempt to discover what contractual practices businessmen actually follow.5 To fill this empirical gap, the Yale Law Journal consulted ten firms in the New Haven area and then composed a Questionnaire which was distributed to 200 Connecticut manufacturers. ${ }^{6}$ One hundred seventy manufacturers were selected from eleven of the state's major industries, while the remaining thirty were chosen from miscellaneous fields. Within each industry the firms in the sample were selected at random, except that whollyowned subsidiaries were excluded. ${ }^{7}$ Eighty-seven, or forty-six per cent of the 188 still solvent and traceable businesses responded to the Questionnaire. ${ }^{8}$ In-

3. 2 Corbin, Contracts $\$ 275$ (1950); 2 Street, Foundations of Legal Liability $196-97$ (1906). This contention in effect challenges the present validity of the original purpose of the Statute to prevent the successful assertion of fraudulent claims on oral contracts proved by perjured testimony. 2 Corain, Contracts $\$ 275$ (1950); Fuller, Basic Contract Law 941-43 (1947); 2 Williston, Contracts 1308 (rev. ed. 1936).

4. See, e.g., Llewellyn, What Price Contract?-An Essay in Perspective, 40 Yale L.J. 704, 740-41, 747-48 (1931); Lilenthal, Judicial Repeal of the Statute of Frauds, 9 Harv. L. REv. 455 (1896); see also authorities cited at 2 Corbin, Contracts $\$ 275$ n.11 (1950); cf. 2 BenLE, CoNflict of Laws 1182 (1935).

At least one critic of the Statute concedes the possibility that it serves its original purpose of preventing the assertion of fraudulent claims. 2 CoRBrn, Conrracts $\$ 275$ (1950).

5. Kessler \& Sharp, Contracts 393 (1953); see also authorities cited, notes 2-4 supra; cf. McCormick, The Parol Evidence Rule as a Procedutral Device for the Control of the Jury, 41 YALE L.J. 365, 366 (1932).

6. The Questionnaire is reprinted in full in the Appendix at pages 1069-71 infra. Although the results of the ten interviews were accorded great weight in constructing the Questionnaire, the data presented represents solely the responses to the Questionnaire itself. And to prevent bias, none of the interviewees was sent a Questionnaire.

7. The sample of 200 firms was taken from the Directory of ConNecticut Manufacturers and Mechanical Establisharents (1954), a compilation of all Connecticut manufacturers. The number of firms selected from any one industry was roughly proportionate to the total number of firms listed in that industrial category. The sample of 200 was comprised of the following types of manufacturers: primary metals (A), 10 firms; fabricated metals (B), 20; instruments and clocks (C), 10; electrical equipment (E), 20; furniture and fixtures $(F), 10$; miscellaneous manufacturing industries (I), 30; leather goods (L), 10; machinery (M), 20; paper (P), 20; rubber (R), 20; stone, clay and glass products (S), 10; and lumber and wood products (W), 20. The code letter following each industrial group will be used throughout to designate a reference to that particular industry.

8. The returned Questionnaires (hereinafter cited as QUESTIONNAIRES) are on file in Yale Law Library.

Five firms had become insolvent and seven others were untraceable. The 87 manufacturers responding represent all the industries in the original sample of 200 , but the per- 
formation was solicited concerning the degree of adherence to the Statute's requirements, the attitude of the manufacturer toward the legal enforceability of oral and written agreements, and the action which he usually takes in the event of a failure to honor an agreement. The data collected afford fresh insight into the role of the Statute of Frauds in the business world and the interests which would be served or adversely affected by its repeal.

\section{The Extent of Business Compliance with the Statute of Frauds}

To determine the extent to which every-day business agreements are rendered unenforceable by the Statute of Frauds, the manufacturers were asked a series of questions designed to indicate the measure of compliance with the Statute in dealings with both customers and suppliers. The responses reveal not only whether the manufacturer obtained enforceable promises in his buying and selling practices, but also whether customers and suppliers could enforce the manufacturer's own commitments to deliver or purchase goods. A transaction was considered enforceable against a customer, or against the manufacturer in his capacity as buyer, if either the initial purchase order or a later confirmation of an oral order was in the form of a memorandum signed by the buyer. A supplier, or the manufacturer as seller, was deemed legally obligated to perform if his acknowledgment of the buyer's order was by signed letter or telegram rather than by telephone or other word of mouth. If the seller's practice was to acknowledge an order only by shipping the goods, his conduct was not considered to fall within the scope of inquiry, since he was deemed to have made no written or oral promise to perform prior to actual performance and thus was not subject to an executory duty which might be legally invalidated by the Statute of Frauds. ${ }^{9}$

centage of responses from each industrial group varies from $20 \%$ (leather goods) to $74 \%$ (electrical equipment). The number of responses from each industry, together with the number of solvent and traceable firms in that industry to which the Questiontairc was sent, is as follows: Industry A, 6 of $10 ; \mathrm{B}, 11 / 20 ; \mathrm{C}, 5 / 8 ; \mathrm{E}, 14 / 19 ; \mathrm{F}, 3 / 10 ; \mathrm{I}, 11 / 2 \mathrm{~s}$; $\mathrm{L}, 2 / 10 ; \mathrm{M}, 10 / 20 ; \mathrm{P}, 7 / 18 ; \mathrm{R}, 8 / 18 ; \mathrm{S}, 5 / 10$; and $\mathrm{W}, 5 / 17$. See note 7 stepra for explanation of the above code letters. Where relevant, later footnotes analyze the practices of each industry to determine whether unequal representation of the various industries biases the figures for the total sample.

It could be argued that the figures are biased because the very fact that a manufacturer responds is indicative of his business practices, and thus the sampling answering the Questionnaire is not truly random with respect to the questions asked. It is possible, for example, that the sample is biased in favor of firms which are used to transacting business by mail and therefore would have responded as a matter of course. See note 10 infra; text at note 19 infra. However, a disproportionately large number of responses might have come from manufacturers who are dissatisfied with the lack of protection which present law affords their oral agreements and are thus desirous of aiding any effort to re-evaluate the worth of the Statute of Frauds. Thus, no conclusion can readily be drawn as to the sample's bias in these respects.

9. This Comment is concerned primarily with the extent to which the Statute of Frauds affects the enforceability of business transactions. Thus, it is necessary to exclude 
For each of the four contracting interests-customers, manufacturer as seller, suppliers, manufacturer as buyer-every firm answering the Questionnaire was given a numerical rating from 0 to 4 . A score of 4 indicates that the party in the stated capacity always obtains agreements which he is not barred from enforcing by the Statute of Frauds; 3 , that he usually does; 2 , that he does in roughly half of his dealings; 1 , that he sometimes does but usually does not: and 0 , that he never does. The scores thus obtained were averaged for the sample as a whole and separately for four groups of firms. Group I includes the 22 firms with less than 25 employees; group II, 34 firms, 25-100 employees ; group III, 22 firms, $101-500$ employees ; and group IV, 9 firms, more than 500 employees. ${ }^{10}$

from the analysis those dealings which would not constitute enforceable agreements even if the Statute did not exist.

If a manufacturer responds that his practice as seller, or the practice of his suppliers, is to acknowledge orders only by shipment of the goods, some difficulty arises in assessing the role played by the Statute in precluding the buyer from collecting damages for the seller's failure to deliver the goods. In most cases, the customer will have no legal remedy for breach of contract, since, prior to shipment of the goods, the seller has not manifested his assent to the offer to purchase goods and thus has not made a contract to which he can be held. See Restatement, Contracts $\$ \$ 20,52$ (1932). Under these circumstances, the existence of the Statute of Frauds is irrelevant.

On the other hand, cases may arise in which the silence of a supplier of goods operates as an acceptance of the buyer's offer and creates a contract prior to his performance. See id. $\$ 72$, illustration 5 . Under these circumstances, the Statute could be the sole cause of the purchaser's inability to enforce the seller's unspoken commitment to deliver the goods as requested. In addition, a few manufacturers specified that oral orders placed with them by their customers, or placed by them with their suppliers, were acknowledged by shipment only. In many of these cases, it is possible that the oral order was orally accepted by some statement made by the seller or his agent to the party communicating the order. Thus, in the absence of the Statute of Frauds, the buyer would be able to sue on the executory bilateral agreement if the seller failed to perform.

If the seller does ship a part of the goods ordered, the Statute of Frauds will probably not prevent the buyer from collecting damages for failure to deliver the remainder of the goods. See UnIForm Sales Act $\$ 4(1)$, (3). Moreover, if the seller ships nonconforming goods, the Statute will not be a bar to the buyer's action for breach of warranty. By accepting the goods, the buyer will render the defense of the Statute inapplicable, ibid., and such acceptance will not preclude the buyer from successfully maintaining his breach of warranty action, id. $\S 49$.

In sum, where a seller designates that he accepts orders by shipment only, the Statute of Frauds would, in the majority of cases, seem not to bar the assertion of legal rights which would otherwise exist. Accordingly, the data given in the text excludes transactions in which a seller acknowledges by shipment only. However, in later footnotes data is separately computed upon the assumption that where acceptance is by shipment only, a buyer is barred from enforcing an executory commitment because of the Statute of Frauds.

10. The distribution of the original sample of 188 firms was as follows: group I, 59; group II, 77; group III, 37; and group IV, 15 . Thus, the percentages of responses received from each group are: I, 37\%; II, $44 \%$; III, 59\%; and IV, $60 \%$. Clearly, then, the figures for the total sample will be influenced more by the responses of the larger manufacturers than if the sample responding were a true cross-section of the firms to which the Questionnaire was sent. Therefore, all data will be presented for each size group as well as for the total sample. 


\section{Overall Compliance}

.The responses indicate that the promises of businessmen usually satisfy the requirements of the Statute of Frauds. For the sample as a whole, the compliance average obtained by weighting equally the four contractual relationships studied was 3.40 -considerably above the 3.00 figure which indicates a pattern of "usual" compliance with the Statute.11 However, the transactions of only 8 of the 87 manufacturers with their customers and suppliers were always characterized by the compliance of both contracting parties. ${ }^{12}$ In addition, the different compliance averages for each of the four contractual relationships, as well as for each of the four size groups of firms, disclose substantial deviations from the overall pattern.

\section{Compliance by Contractual Relationships}

Of the contractual relationships, the highest compliance average was 3.67 . measuring the extent to which a manufacturer as buyer furnishes a supplier with a written memorandum of the transaction. This average reflects the data that suppliers of $70 \%$ of the manufacturers responding always obtain agreements enforceable despite the Statute of Frauds, and suppliers of another $28 \%$ usually do. ${ }^{13}$ The compliance average for the extent to which a manufacturer's customers provide him with signed memoranda of their purchase requests was 3.13 , the lowest figure for any contractual relationship. Less than half of the

11. The compliance averages for each of the contractual interests are: customers, 3.49 : manufacturer as seller, 3.13 ; suppliers, 3.67 ; and manufacturer as buyer, 3.30. See notes 13-16 infra and accompanying text. Although the sample is admittedly small, the probability is less than five in one hundred that these averages for the entire business community lie outside the following limits: customers, 3.32-3.66; manufacturer as seller, 2.903.36; suppliers, 3.55-3.79; and manufacturer as buyer, 3.15-3.45. See 2 KenNEY \& KEEPing, Mathematics of Statistics 134 (2d ed. 1951).

In accordance with the method described in note 9 supra and accompanying text, the compliance averages exclude transactions in which the manufacturer as seller, or a supplier, acknowledges orders only by shipment of goods. If these transactions are included in the analysis, the respective compliance averages for each of the above contractual interests become $2.84,(3.13),(3.67)$, and 2.78. The overall compliance average obtained by equally weighting these averages is 3.11 , indicating that, if acceptance by shipment only rather than by writing is considered as non-compliance with the Statute of Frauds, business transactions still "usually" result in enforceable agreements. Since the Statute will affect the enforceability of some transactions in which acknowledgment is "by shipment only," see note 9 supra, the true overall compliance average of the sample responding for the extent to which agreements are not rendered unenforceable by the Statute lies somewhere between 3.11 and 3.40 .

In computing these overall compliance averages, the averages for each of the four contractual interests, rather than the raw data, were used in order to prevent bias in favor of an interest represented by a greater number of responses. However, use of the raw data would not appreciably change the figures, as the averages for the interests of customers and manufacturer as seller are based on 80 and 87 responses respectively, and those for the interests of suppliers and the manufacturer as buyer, on 83 and 82 responses respectively. See notes 13-16 infra.

12. These 8 manufacturers represent the following industries and size groups: $R, I$; W, I; E, II ; A, III (2) ; P, III; E, IV; and P, IV. See Questionnaires.

13. The data on which the above compliance average and percentages are based as well as the distribution of responses and compliance averages for each industrial group 
manufacturers always enjoy such security from their customers, while another third usually do. ${ }^{14}$ Thus, the responses to the Questionnaire indicate that

are given by Table I below. It can be seen that while some variation by industry exists, the extent of compliance is consistently high for this contractual relationship. These figures result from an analysis of the answers to questions 13 and 14 of the Questionnaire. See Appendix, page 1071 infra.

\begin{tabular}{|c|c|c|c|c|c|c|c|c|c|c|c|c|c|c|}
\hline \multirow[b]{2}{*}{ RESPONSE } & \multicolumn{12}{|c|}{ INDUSTRY* } & \multirow[b]{2}{*}{ Total } & \multirow[b]{2}{*}{$\begin{array}{l}\text { Per } \\
\text { cent }\end{array}$} \\
\hline & A & B & C & $\mathrm{E}$ & $F$ & $I$ & L & $\mathrm{M}$ & P & $\mathrm{R}$ & $\mathrm{S}$ & W & & \\
\hline (Never) 0 & 0 & 0 & 0 & 0 & 0 & 0 & 0 & 0 & 0 & 0 & 0 & 0 & 0 & 0 \\
\hline 1 & 0 & 0 & 0 & 0 & 0 & 0 & 0 & 0 & 0 & 0 & 0 & 0 & 0 & 0 \\
\hline 2 & 0 & 0 & 0 & 1 & 0 & 0 & 0 & 1 & 0 & 0 & 0 & 0 & 2 & 2 \\
\hline 3 & 3 & 1 & 1 & 0 & 2 & 4 & 2 & 5 & 3 & 0 & 0 & 2 & 23 & 28 \\
\hline (Always) 4 & 3 & 10 & 3 & 13 & 1 & 6 & 0 & 4 & 4 & 7 & 4 & 3 & 58 & 70 \\
\hline $\begin{array}{r}\text { Total } \\
\text { Responses }\end{array}$ & 6 & 11 & 4 & 14 & 3 & 10 & 2 & 10 & 7 & 7 & 4 & 5 & 83 & 100 \\
\hline $\begin{array}{r}\text { Compliance } \\
\text { Averages }\end{array}$ & 3.50 & 3.91 & 3.75 & 3.86 & 3.33 & 3.60 & 3.00 & 3.33 & 3.57 & 4.00 & 4.00 & 3.60 & 3.67 & \\
\hline
\end{tabular}

\section{* See note 7 supra.}

TABLE I

Extent to which Manufacturers in Each Industry Furnish

Suppliers with Signed Memoranda of Purchase Requests

14. The data on which these figures are based are given in Table II below for the total sample and for each industrial group. While some variation by industry appears to exist, the compliance averages for all but one industrial group represented by more than five manufacturers are consistently above 3.00. These figures result from an analysis of the answers to questions 3,4 and 5 of the Questionnaire. See Appendix page 1069 infra.

\begin{tabular}{|c|c|c|c|c|c|c|c|c|c|c|c|c|c|c|}
\hline & \multicolumn{12}{|c|}{ INDUSTRY* } & \multirow[b]{2}{*}{ Total } & \multirow[b]{2}{*}{$\begin{array}{l}\text { Per } \\
\text { cent }\end{array}$} \\
\hline Response & A & B & & $\mathrm{C} \quad \mathrm{E}$ & $F$ & I & L & $\mathrm{M}$ & $P$ & $\mathrm{R}$ & $\mathrm{S}$ & W & & \\
\hline (Never) 0 & 0 & 0 & & 2 & 1 & 0 & 0 & 0 & 0 & 0 & 0 & 0 & 3 & 4 \\
\hline 1 & 0 & 2 & & 0 & 0 & 1 & 1 & 2 & 1 & 0 & 0 & 0 & 7 & 8 \\
\hline 2 & 0 & 1 & 0 & 0 & 1 & 4 & 0 & 0 & 0 & 0 & 0 & 0 & 7 & 8 \\
\hline 3 & 3 & 2 & & 1. & 0 & 3 & 0 & 2 & 3 & 5 & 2 & 4 & 29 & 33 \\
\hline (Always) 4 & 3 & $\overline{6}$ & & 2 & 1 & 3 & 1 & 6 & 3 & 3 & 3 & 1 & 41. & 47 \\
\hline $\begin{array}{r}\text { Total } \\
\text { Responses }\end{array}$ & 6 & 11 & & $\begin{array}{ll}5 & 14\end{array}$ & 3 & 11 & 2 & 10 & 7 & 8 & 5 & 5 & 87 & 100 \\
\hline $\begin{array}{r}\text { Compliance } \\
\text { Averages }\end{array}$ & 3.50 & 3.09 & 2.20 & 03.56 & 2.00 & 2.73 & 2.50 & 3.20 & 3.14 & 3.38 & 3.60 & 3.20 & 3.13 & \\
\hline
\end{tabular}

* See note 7 supra.

TABLE II

Extent to which Manufacturers in Each Industry Receive from Customers Signed Memoranda of Purchase Requests 
manufacturers are more likely to send signed orders to their suppliers than their customers are to send signed orders to them. The frequency of manufacturers' acknowledging customers' orders in writing rather than orally produced a compliance average of 3.49 , indicating that any acknowledgment is more than "usually" written. The acknowledgments of $60 \%$ of the manufacturers are always by signed memoranda, while an additional $32 \%$ usually acknowledge in writing. ${ }^{15}$ Oral acknowledgments of manufacturers' orders by their suppliers are somewhat more common than oral acknowledgments by the manufacturers of their own customers' orders. The compliance average for a manufacturer's ability to enforce his suppliers' promises despite the Statute of Frauds was 3.30 . Only $38 \%$ of the manufacturers always obtain

15. The data on which these figures are based are given for the total sample and for each industrial group in Table III below. The responses are highly consistent throughout all industries. Table IV shows the comparable distribution of responses and compliance averages when transactions in which the manufacturer acknowledges by shipment only arc included in the analysis. The reason for the different number of responses in the two Tables is that seven manufacturers always acknowledge orders by shipment only. See note 9 supra. The figures in both Tables are based on the answers to questions $3,4,9$ and 10 of the Questionnaire. See Appendix, pages 1069-70 infra.

The fact that the compliance averages in Table III are substantially higher than those in Table IV, and the similar relationship between the averages in Table V and Table VI, note 16 infra, indicate that sellers often acknowledge orders only by shipping the goods requested.

\begin{tabular}{|c|c|c|c|c|c|c|c|c|c|c|c|c|c|c|}
\hline \multirow[b]{2}{*}{ RESPONSE } & \multicolumn{12}{|c|}{ INDUSTRY* } & \multirow[b]{2}{*}{ Total } & \multirow[b]{2}{*}{$\begin{array}{l}\text { Per } \\
\text { cent }\end{array}$} \\
\hline & A & B & $\mathrm{C}$ & $\mathrm{E}$ & $F$ & $I$ & $I$ & $M$ & $P$ & R & $S$ & W & & \\
\hline (Never) 0 & 0 & 0 & 0 & 0 & 0 & 0 & 0 & 0 & 0 & 0 & 0 & 0 & 0 & 0 \\
\hline 1. & 0 & 1 & 0 & 0 & 0 & 0 & 0 & 1 & 0 & 0 & 1 & 0 & 3 & 4 \\
\hline 2 & 0 & 0 & 0 & 1 & 0 & 0 & 0 & 1 & 1 & 0 & 0 & 0 & 3 & 4 \\
\hline 3 & 2 & 3 & 0 & 5 & 0 & 5 & 1 & 3 & 2 & 2 & 0 & 3 & 26 & 32 \\
\hline (Always) 4 & 3 & 6 & 4 & 8 & 2 & 5 & 1 & 5 & 4 & 4 & 4 & 2 & 48 & 60 \\
\hline $\begin{array}{r}\text { Total } \\
\text { Responses }\end{array}$ & 5 & 10 & 4 & 14 & 2 & 10 & 2 & 10 & 7 & 6 & 5 & 5 & 80 & 100 \\
\hline $\begin{array}{r}\text { Compliance } \\
\text { Averages }\end{array}$ & 3.60 & 3.40 & 4.00 & 3.50 & 4.00 & 3.50 & 3.50 & 3.20 & 3.43 & 3.67 & 3.40 & 3.40 & 3.49 & \\
\hline
\end{tabular}

* See note 7 supra.

TABLE III

Extent to which Manufacturers in Each Industry Furnish Customers with Signed rather than Oral Acknowledgments 
written rather than oral acknowledgments from their suppliers; $57 \%$ usually do. ${ }^{10}$

\begin{tabular}{|c|c|c|c|c|c|c|c|c|c|c|c|c|c|c|}
\hline & \multicolumn{12}{|c|}{ INDUSTRX } & \multirow[b]{2}{*}{ Total } & \multirow[b]{2}{*}{$\begin{array}{l}\text { Per } \\
\text { cent }\end{array}$} \\
\hline Response & $\mathrm{A}$ & B & C & $E$ & $F$ & $\mathrm{I}$ & $\mathrm{L}$ & $\mathrm{M}$ & $\mathrm{P}$ & $\mathrm{R}$ & $S$ & $\mathrm{~W}$ & & \\
\hline (Never) 0 & 1 & 0 & 1 & 0 & 1 & 1 & 0 & 0 & 0 & 2 & 0 & 0 & 6 & 7 \\
\hline 1 & 0 & 4 & 0 & 2 & 1 & 2 & 0 & 1 & 0 & 0 & 1 & 0 & 11 & 13 \\
\hline 2 & 0 & 0 & 0 & 2 & 0 & 0 & 1 & 3 & 1 & 0 & 1 & 2 & 10 & 11 \\
\hline 3 & 3 & 3 & 2 & 3 & 0 & 4 & 0 & 3 & 3 & 2 & 0 & 1 & 24 & 28 \\
\hline (Always) 4 & 2 & 4 & 2 & 7 & 1 & 4 & 1 & 3 & 3 & 4 & 3 & 2 & 36 & 41 \\
\hline $\begin{array}{r}\text { Total } \\
\text { Responses }\end{array}$ & 6 & 11. & 5 & 14 & 3 & 11 & 2 & 10 & 7 & 8 & 5 & 5 & 87 & 100 \\
\hline $\begin{array}{r}\text { Compliance } \\
\text { Averages }\end{array}$ & 2.83 & 2.64 & 2.80 & 3.07 & 1.67 & 2.73 & 3.00 & 2.80 & 3.29 & 2.75 & 3.00 & 3.00 & 2.84 & \\
\hline
\end{tabular}

$\because$ See note 7 supra.

TABLE IV

Extent to which Manufacturers in Each Industry Furnish

Customers with Signed Acknowledgments rather than Oral

Acknowledgments or Acknowledgments by Shipment Only

16. The data on which these figures are based are given for the total sample and for each industrial group in Table $\mathrm{V}$ below. Only slight variation by industry exists. Table VI shows the comparable distribution of responses and compliance averages when transactions in which the supplier acknowledges by shipment only are included in the analysis. See note 9 supra. The figures in both Tables are based on the answers to questions 15 and 16 of the Qucstionnaire. See Appendix, page 1071 infra. For explanation of the different number of responses and the different compliance averages in the two Tables, see note 15 supra.

\begin{tabular}{|c|c|c|c|c|c|c|c|c|c|c|c|c|c|c|}
\hline & \multicolumn{12}{|c|}{ INDUSTRY* } & \multirow[b]{2}{*}{ Total } & \multirow[b]{2}{*}{$\begin{array}{l}\text { Per } \\
\text { cent }\end{array}$} \\
\hline Response & A & $\mathrm{B}$ & C & $\mathrm{E}$ & $\mathrm{F}$ & $I$ & $\mathrm{~L}$ & $\mathrm{M}$ & $\mathrm{P}$ & R & $\mathrm{S}$ & $\mathrm{W}$ & & \\
\hline (Never) 0 & 0 & 0 & 0 & 0 & 0 & 0 & 0 & 1 & 0 & 0 & 0 & 0 & 1 & 1 \\
\hline 1 & 0 & 0 & 0 & 0 & 0 & 0 & 0 & 0 & 0 & 0 & 0 & 0 & 0 & 0 \\
\hline 2 & 0 & 0 & 1 & 0 & 0 & 0 & 0 & 1 & 0 & 0 & 1 & 0 & 3 & 4 \\
\hline 3 & 4 & 8 & 2 & 10 & 2 & 3 & 1 & 7 & 1. & 4 & 4 & 1 & 47 & 57 \\
\hline (Always) 4 & 2 & 3 & 1 & 4 & 0 & 6 & 1 & 1 & 6 & 4 & 0 & 3 & 31 & 38 \\
\hline $\begin{array}{r}\text { Total } \\
\text { Responses }\end{array}$ & 6 & 11 & 4 & 14 & 2 & 9 & 2 & 10 & 7 & 8 & 5 & 4 & 82 & 100 \\
\hline $\begin{array}{r}\text { Compliance } \\
\text { Averages }\end{array}$ & 3.33 & 3.27 & 3.00 & 3.29 & 3.00 & 3.67 & 3.50 & 2.70 & 3.86 & 3.50 & 2.80 & 3.75 & 3.30 & \\
\hline
\end{tabular}

* See note 7 supra.

TABLE V

Extent to which Manufacturers in Each Industry Receive from Suppliers Signed rather than Oral Acknowledgments 
On the basis of the preceding data, it may be concluded that the Statute of Frauds bars enforcement of promises made to manufacturers more often than promises made by them. It may also be noted that the Statute affects buyers as a class and sellers as a class about equally, the overall compliance average for each of these two groups being 3.40.17 In addition, the incidence of oral agreements in the transactions between a manufacturer and his customers is slightly higher than in dealings between a manufacturer and his suppliers, as shown by the overall compliance averages of 3.31 and 3.49 for the two respective contractual areas. ${ }^{18}$

\section{Compliance by Size Group}

The responses also reveal what appears to be a direct relationship between the size of a manufacturing firm and the likelihood that the manufacturer and

\begin{tabular}{|c|c|c|c|c|c|c|c|c|c|c|c|c|c|c|}
\hline \multirow[b]{2}{*}{ RESPONSE } & \multicolumn{12}{|c|}{ INDUSTRY* } & \multirow[b]{2}{*}{ Total } & \multirow[b]{2}{*}{$\begin{array}{l}\text { Per } \\
\text { cent }\end{array}$} \\
\hline & A & $\mathrm{B}$ & $\mathrm{C}$ & $\mathrm{E}$ & $\mathrm{F}$ & I & $\begin{array}{l}\text { I } \\
\text { D }\end{array}$ & $\mathrm{M}$ & $\mathrm{P}$ & $\mathrm{R}$ & $\mathrm{S}$ & W & & \\
\hline (Never) 0 & 0 & 0 & 1 & 0 & 1 & 0 & 0 & 1 & 0 & 0 & 0 & 0 & 3 & 4 \\
\hline 1 & 0 & 0 & 0 & 0 & 0 & 0 & 0 & 0 & 0 & 1 & 0 & 1 & 2 & 2 \\
\hline 2 & 0 & 2 & 1 & 2 & 0 & 2 & 0 & 3 & 0 & 1 & 1 & 1 & 13 & 15 \\
\hline 3 & 6 & 7 & 3 & 10 & 2 & 6 & 2 & 6 & 5 & 5 & 4 & 2 & 58 & 69 \\
\hline (Always) 4 & 0 & 2 & 0 & 2 & 0 & 1 & 0 & 0 & 2 & 1 & 0 & 0 & 8 & 10 \\
\hline $\begin{array}{r}\text { Total } \\
\text { Responses }\end{array}$ & 6 & 11 & 5 & 14 & 3 & 9 & 2 & 10 & 7 & 8 & 5 & 4 & 84 & 100 \\
\hline $\begin{array}{r}\text { Compliance } \\
\text { Averages }\end{array}$ & 3.00 & 3.00 & 2.20 & 3.00 & 2.00 & 2.89 & 3.00 & 2.40 & 3.29 & 2.75 & 2.80 & 2.25 & 2.78 & \\
\hline
\end{tabular}

* See note 7 supra.

TABIE VI

Extent to which Manufacturers in Each Industry Receive from Suppliers Signed Acknowledgments rather than Oral Acknowledgments or Acknowledgments by Shipment Only

17. The compliance average for buyers as a class is simply the arithmetical mean of the compliance averages for the manufacturer's ability to enforce the promises of his supplier (3.30) and the customer's ability to enforce those of the manufacturer (3.49). Similarly, the figure for sellers as a class is the mean of the compliance averages for the manufacturer's ability to enforce the orders of his customers (3.13) and the supplier's ability to enforce those of the manufacturer (3.67). See notes 13-16 supra and accompanying text.

18. The overall compliance average for each of the two contractual areas is the mean of the compliance averages for the two contractual interests which comprise the area. Thus, the 3.31 figure is the mean of the compliance averages for the customer's ability to enforce the promises of the manufacturer (3.49) and the manufacturer's ability to enforce those of his customer (3.13). See notes 14-15 supra and accompanying text. 
the parties with whom he deals comply with the Statute. The overall compliance average for group I was 3.07 ; for group II, 3.37 ; for group III, 3.65; and for group IV, 3.69.19 This correlation between size and compliance is most evident in the figures indicating whether a manufacturer obtains signed agreements from his customers. The compliance averages for this contractual relationship were group I, 2.73 ; group II, 2.97; group III, 3.50 ; and group IV, 3.78. The fact that a large manufacturer is more likely than a small manufacturer to have a contract enforceable against his customers is further illustrated by the finding that the customers of only $27 \%$ of the firms in group I always send signed orders, while the customers of $78 \%$ of the group IV firms always do. The comparable figures for groups II and III are $41 \%$ and $64 \%$ respectively. ${ }^{20}$

A noteworthy, though less striking, correlation exists between the size of the manufacturer and the probability that he will arm his customer with an enforceable rather than oral acknowledgment. The compliance average in this area for group I was 2.95 , and the promises of only $20 \%$ of the firms in this group are always enforceable by their customers. The comparable figures for the other three groups were: group II, 3.53 and $63 \%$; group III, 3.81 and

19. The overall compliance averages are computed by taking the mean of the compliance averages for all contractual interests. See note 11 supra. For the data on which these compliance averages are based, see notes 20-23 infra and accompanying text.

20. The distribution of all responses in this area for each size group of manufacturers is presented in Table VII below. For this contractual relationship, the probability that the difference between the average of groups I and II combined (2.87) and that of groups III and IV combined (3.58) occurred by chance is less than one in four hundred. See 2 KENNEY \& KEEPING, op. cit. supra note 11, at 160, 162, 178.

\begin{tabular}{|c|c|c|c|c|c|}
\hline & \multicolumn{4}{|c|}{ Size GrouP* } & \\
\hline RESPONSE & $\bar{I}$ & $\overline{\text { II }}$ & III & IV & Total \\
\hline (Never) 0 & 2 & 1 & 0 & 0 & 3 \\
\hline 1 & 2 & 4 & 1 & 0 & 7 \\
\hline 2 & 2 & 4 & 1 & 0 & 7 \\
\hline 3 & 10 & 11 & 6 & 2 & 29 \\
\hline (Always) 4 & 6 & 14 & 14 & 7 & 41 \\
\hline $\begin{array}{r}\text { Total } \\
\text { Responses }\end{array}$ & 22 & 34 & 22 & 9 & 87 \\
\hline $\begin{array}{r}\text { Compliance } \\
\text { Averages }\end{array}$ & 2.73 & 2.97 & 3.50 & 3.78 & 3.13 \\
\hline
\end{tabular}

* See text at note 10 supra.

TABLE VII

Extent to which Different Size Manufacturers Receive from Customers Signed Memoranda of Purchase Requests 
$81 \%$; and group IV, 3.78 and $89 \% .^{21}$ The ability of a manufacturer to hold his suppliers through the receipt of signed acknowledgments varies directly with the size of the manufacturer, though for this contractual relationship as well as the preceding one the compliance averages for groups III and IV were essentially the same. The figures for each of the four size groups were: I, 3.11: II, 3.31; III, 3.41; and IV, 3.44. Suppliers' acknowledgments are always enforceable by the following percentages of manufacturers: group $I$,

21. The distribution of all responses in this area for each size group of manufacturers is presented in Table VIII below. The probability that the differences apparent in this Table between the averages of groups I and II combined (3.30) and that of groups III and IV combined (3.80) occurred by chance is less than one in two hundred fifty. Ibid. Table IX shows the comparable distribution of responses and compliance averages when transactions in which the manufacturer acknowledges by shipment only are included in the analysis. See note 9 supra.

\begin{tabular}{|c|c|c|c|c|c|}
\hline & \multicolumn{4}{|c|}{ SIze Group* } & \\
\hline RESPONSE & I & II & III & IV & Total \\
\hline (Never) 0 & 0 & 0 & 0 & 0 & 0 \\
\hline 1 & 2 & 1 & 0 & 0 & 3 \\
\hline 2 & 1 & 1 & 0 & 1 & 3 \\
\hline 3 & 13 & 9 & 4 & 0 & 26 \\
\hline (Always) 4 & 4 & 19 & 17 & 8 & 48 \\
\hline $\begin{array}{r}\text { Total } \\
\text { Responses }\end{array}$ & 20 & 30 & 21 & 9 & 80 \\
\hline $\begin{array}{r}\text { Compliance } \\
\text { Averages }\end{array}$ & 2.95 & 3.53 & 3.81 & 3.78 & 3.49 \\
\hline
\end{tabular}

* See text at note 10 supra.

TABLE VIII

Extent to which Different Size Manufacturers Furnish Customers with Signed rather than Oral Acknowledgments

\begin{tabular}{|c|c|c|c|c|c|}
\hline & \multicolumn{4}{|c|}{ Size Group } & \multirow[b]{2}{*}{ Total } \\
\hline RESPONSE & I & II & III & I IV & \\
\hline (Never) 0 & 2 & 4 & 0 & 0 & 6 \\
\hline 1 & 4 & 3 & 3 & 1 & 11 \\
\hline 2 & 2 & 7 & 0 & 1 & 10 \\
\hline 3 & 10 & 7 & 5 & 2 & 24 \\
\hline (Always) 4 & 4 & 13 & 14 & 5 & 36 \\
\hline $\begin{array}{r}\text { Total } \\
\text { Responses }\end{array}$ & 22 & 34 & 22 & 9 & 87 \\
\hline $\begin{array}{r}\text { Compliance } \\
\text { Averages }\end{array}$ & 2.45 & 2.65 & 3.36 & 3.22 & 2.84 \\
\hline & * S & ex & no & $10 s$ & ra. \\
\hline
\end{tabular}

Extent to which Different Size Manufacturers Furnish Customers with Signed Acknowledgments rather than Oral Acknowledgments or Acknowledgments by Shipment Only 
$42 \%$; group II, $31 \%$; group III, $41 \%$; and group IV, $44 \% .{ }^{22}$ The extent to which a supplier can enforce the obligations of a manufacturing firm with whom he does business also varies with the size of the manufacturer, but since the compliance average of each size group for this relationship is extremely high, the differences according to manufacturer's size are of limited significance. The compliance averages and the percentages of the manufacturers

22. Table $\mathrm{X}$ below gives the distribution of all responses in this area by the size of the manufacturer responding. Table XI presents the comparable distribution of responses and compliance averages when transactions in which the supplier acknowledges by shipment only are included in the analysis. See note 9 supra. For discussion of the significance of the different compliance averages in Tables $\mathrm{X}$ and XI, as well as of the differences in responses in Tables VIII and IX, note 21 supra, see note 15 supra.

\begin{tabular}{|r|rrrr|r|}
\cline { 2 - 7 } \multicolumn{1}{c|}{} & \multicolumn{4}{|c|}{ SIzE Group* } & \\
\hline Response & I & II & III & IV & Total \\
\hline (Never) 0 & 1 & 0 & 0 & 0 & 1 \\
\hline 1 & 0 & 0 & 0 & 0 & 0 \\
\hline 2 & 3 & 0 & 0 & 0 & 3 \\
\hline 3 & 7 & 22 & 13 & 5 & 47 \\
\hline$($ Always) 4 & 8 & 10 & 9 & 4 & 31 \\
\hline $\begin{array}{r}\text { Total } \\
\text { Responses }\end{array}$ & 19 & 32 & 22 & 9 & 82 \\
\hline $\begin{array}{r}\text { Compliance } \\
\text { Averages }\end{array}$ & 3.11 & 3.31 & 3.41 & 3.44 & 3.30 \\
\hline
\end{tabular}

* See text at note 10 supra.

TABLE X

Extent to which Different Size Manufacturers Receive from Suppliers Signed rather than Oral Acknowledgments

\begin{tabular}{|r|rccc|c}
\cline { 2 - 6 } \multicolumn{1}{c|}{} & \multicolumn{4}{|c|}{ Stze Group* } & \\
\hline REsponse & I & II & III & IV & Total \\
\hline (Never) 0 & 2 & 1 & 0 & 0 & 3 \\
\hline 1 & 1 & 1 & 0 & 0 & 2 \\
\hline 2 & 7 & 1 & 5 & 0 & 13 \\
\hline 3 & 8 & 27 & 17 & 6 & 58 \\
\hline (Always) 4 & 2 & 3 & 0 & 3 & 8 \\
\hline $\begin{array}{r}\text { Total } \\
\text { Responses }\end{array}$ & 20 & 33 & 22 & 9 & 84 \\
\hline $\begin{array}{r}\text { Compliance } \\
\text { Averages }\end{array}$ & 2.35 & 2.91 & 2.77 & 3.33 & 2.78 \\
\hline
\end{tabular}

* See text at note 10 supra.

TABLE XI

Extent to which Different Size Manufacturers Receive from Suppliers Signed Acknowledgments rather than Oral Acknowledgments or Acknowledgments by Shipment Only 
whose suppliers always obtain a signed statement of the purchase were $\mathrm{I}, 3.50$, $50 \%$; II, 3.66, 69\%; III, 3.86, 86\% ; and IV, 3.75, $88 \% . .^{23}$

Thus, the compliance averages for all four contractual relationships indicate that the practice of tendering and receiving oral promises varies substantially with the size of the manufacturer, except that only inconclusive differences exist between the averages of firms with 100-500 employees and those with over 500 employees. ${ }^{24}$ However, since in all relationships the percentages of "always complying" responses were highest for the latter group of firms," a larger sample might well disclose a perfect correlation between the size of the manufacturer and the frequency of compliance with the Statute by the manufacturer and the parties with whom he deals.

\section{Conclusion}

The foregoing tabulations disclose that while contractual dealings of businessmen generally meet the requirements of the Statute of Frauds, a limited number of agreements are rendered legally unenforceable by the Statute. This conclusion is especially true in the area of a small manufacturer's transactions with his customers. For firms with no more than twenty-five employees, the compliance averages for both the customer's ability to enforce the manufacturer's commitments and the manufacturer's ability to hold his customer were

23. The distribution of all responses bearing on this contractual interest is given by the size of the manufacturer responding in Table XII below.

\begin{tabular}{|c|c|c|c|c|c|}
\hline & \multicolumn{4}{|c|}{ SIzE GrouP* } & \\
\hline RESPONSE & $I$ & II & III & IV & Total \\
\hline (Never) 0 & 0 & 0 & 0 & 0 & 0 \\
\hline 1 & 0 & 0 & 0 & 0 & 0 \\
\hline 2 & 0 & 1. & 0 & 1 & 2 \\
\hline 3 & 11 & 9 & 3 & 0 & 23 \\
\hline (Always) 4 & 11 & 22 & 18 & 7 & 58 \\
\hline $\begin{array}{r}\text { Total } \\
\text { Responses }\end{array}$ & 22 & 32 & 21 & 8 & 83 \\
\hline $\begin{array}{r}\text { Compliance } \\
\text { Averages }\end{array}$ & 3.50 & 3.66 & 3.86 & 3.75 & 3.67 \\
\hline
\end{tabular}

* See text at note 10 supra.

TABLE XII

Extent to which Different Size Manufacturers Furnish Suppliers with Signed Memoranda of Purchase Requests

24. See notes 20-23 supra and accompanying text.

25. Ibid. 
less than $3.00,{ }^{26}$ indicating a pattern of less than "usual" compliance with the Statute. The same pattern emerges for the ability of the slightly larger manufacturer-one with 25 to 100 employees-to enforce orders of his customers. ${ }^{27}$ With these three exceptions, all compliance averages for each size group in each contractual relationship were well above the 3.00 dividing line, thus signifying that a relatively small number of promises in ordinary business dealings are not legally binding because of the Statute of Frauds. The discovery that oral promises are more prevalent in the transactions of small manufacturers than in the dealings of large ones is not surprising. As shown by the responses, the reduction to writing of all commitments-both of the manufacturer and of the parties with whom he deals-is an important factor in the efficient operation of the modern large-scale business organization. A small manufacturer, handling a more limited volume of business on a more personal basis, is likely to find strict adherence to business formalities both more foreign to the nature of his business relationships and less necessary in the interest of efficiency. ${ }^{28}$

\section{The Extent to Which Written Documents Are Requested}

In addition to indicating how frequently business agreements in fact comply with the Statute of Frauds, the responses to the Questionnaire also revealed to what extent manufacturers actually request documents signed by the other contracting party, in contrast to voluntary tender of such documents by the promisor. Thus, the manufacturers disclosed whether they require written rather than oral acknowledgment of an order placed with a supplier, or written confirmation of an oral order received from a customer. ${ }^{29}$ These responses were thought crucial in determining whether businessmen feel the need to possess the documents required by the Statute as a condition of enforcing their promisors' agreements. The overall compliance average for the likelihood that a manufacturer, given an oral acknowledgment of an order placed with a supplier, would still insist upon a written one was only 1.61 , indicating that a manufacturer would require such written acknowledgment less than half of the time. The compliance averages for this question again varied directly with the size of the manufacturer, as shown by the following scores: size group I, 1.25 ; II, 1.45 ; III, 1.64 ; and IV, 2.89 . Only eight of the 84 manufacturers responding would always require that a written acknowledgment follow an

26. See notés 20,21 supra and accompanying text.

27. See note 20 supra and accompanying text.

28. The comment of one medium-size manufacturer ( 200 employees) may well describe prevailing business practices: "When dealing with large corporations everything must be spelled out, confirmed, etc. When dealing with small companies, or where dealing direct with top management, a much more informal basis is established." Questionnaires.

29. See questions 5 and 16 of the Questionnaire, Appendix, pages 1069, 1071 infra. 
oral one; two were in group I (10\% of the group); three in group II $(10 \%)$, and three in group IV $(33 \%) .{ }^{30}$

In contrast to these exceedingly low scores, the overall compliance average for the extent to which a manufacturer will request a written confirmation of a customer's oral order was 2.76 . Forty-one of 87 manufacturers always require such confirmation. The differences in this area for the various size groups of firms were also striking, and clearly indicated that the larger the manufacturer, the greater the likelihood that his practice is to require confirmation. The compliance average for group I was 2.18, indicating that firms with less than 25 employees request written confirmation of oral orders slightly more often than they do not. For group II, the figure was 2.56, while for groups III and IV, it rose to 3.32 and 3.56 respectively. The percentages of each size group which always requested confirmation were group I, $27 \%$; group II,

30. The distribution of all responses to this question, as well as the compliance averages, are given for the total sample and by the size of the manufacturer in Table XIII below. The probability that the differences apparent in this Table between the averages of groups I and II combined (1.38) and that of groups III and IV combined (2.00) occurred by chance is less than three in one hundred. Se'e 2 Kenney \& KeEping, op. cit. supra note 11 , at $160-62,178$.

\begin{tabular}{|r|rrrr|r|r|}
\cline { 2 - 7 } \multicolumn{1}{c|}{} & \multicolumn{5}{c|}{ SIze Grou** } & \multicolumn{1}{c|}{} \\
\hline REsponse & I & II & III & IV & Total & Per cent \\
\hline (Never) 0 & 5 & 6 & 0 & 0 & 11 & 13 \\
\hline 1. & 11 & 18 & 15 & 2 & 46 & 55 \\
\hline 3 & 2 & 6 & 7 & 4 & 19 & 23 \\
\hline $\begin{array}{r}\text { (Always) } 4 \\
\text { Total } \\
\text { Responses }\end{array}$ & 2 & 3 & 0 & 3 & 8 & 9 \\
\hline $\begin{array}{r}\text { Compliance } \\
\text { Averages }\end{array}$ & 1.18 & 1.45 & 1.64 & 2.89 & 1.61 & \\
\hline
\end{tabular}

* See text at note 10 supra.

TABLE XIII

Extent to which Different Size Manufacturers Request from Their Suppliers Written Confirmation of Oral Acknowledgments 
$41 \%$; group III, $64 \%$; and group IV, $78 \% .^{31}$ Thus, all the figures for this question-both compliance averages for each size group and the percentages responding "always"-were much higher than the comparable figures for the question whether written acknowledgment following a supplier's oral acknowledgment is required. ${ }^{32}$

Still, it is doubtful whether this data necessarily leads to the conclusion that businessmen are more anxious to have legally binding commitments from their

31. Table XIV below gives the distribution of all responses to this question for the total sample and by the size of the manufacturer. The probability that the differences apparent in this Table between the averages of groups I and II combined (2.41) and that of groups III and IV combined (3.39) occurred by chance is less than one in four hundred. Ibid.

\begin{tabular}{|r|rrrr|c|c|}
\cline { 2 - 7 } \multicolumn{1}{c|}{} & \multicolumn{5}{c|}{ Size Group* } & \multicolumn{1}{c|}{} \\
\hline Response & I & II & III & IV & Total & Per cent \\
\hline (Never) 0 & 4 & 5 & 1 & 0 & 10 & 12 \\
\hline 1 & 6 & 7 & 2 & 1 & 16 & 18 \\
\hline 3 & 6 & 8 & 5 & 1 & 20 & 23 \\
\hline $\begin{array}{r}\text { (Always) } 4 \\
\text { Tespotal }\end{array}$ & 6 & 14 & 14 & 7 & 41 & 47 \\
\hline $\begin{array}{r}\text { Cornpliance } \\
\text { Averages }\end{array}$ & 2.18 & 2.56 & 3.32 & 3.56 & 2.76 & \\
\hline
\end{tabular}

*See text at note 10 supra.

TABLE XIV

Extent to which Different Size Manufacturers Request from Their Customers Written Confirmation of Oral Orders

32. The marked difference between the incidence of manufacturers' requests for written documents from (a) suppliers and (b) customers does not eliminate the possibility of consistency in the practice followed by any given manufacturer when faced with an oral commitment from either type of promisor. This would be so if, e.g., manufacturers who always request written confirmation from customers usually request such documents from suppliers, and manufacturers who sometimes request written confirmation from customers never make such a request to suppliers. If such a consistent pattern exists, it could be argued that businessmen seek some general level of legal security in all their dealings, even though this level varies to some extent with the nature of the transaction. However, the relevant statistical measure shows only a minimal relationship between the two sets of data. The coefficient of correlation was +.20 for the total sample and $+.09,+.18,+.26$, and -.47 for groups I ( 20 firms), II (33 firms), III ( 22 firms), and IV ( 9 firms) respectively. See $i d$. at 69 . None of these figures is significantly different from a zero score which would indicate that no correlation exists between the practice of requesting written documents from suppliers and that of requesting them from customers. See $i d$. at 215. 
customers than from their suppliers. Even if the manufacturer feels an equal need to exact enforceable promises from both classes of parties with whom he deals, he might be more prone to require written confirmations in dealings with his customers because of factors which do not come into play in transactions with suppliers. When a manufacturer receives an order from a customer, it is the manufacturer himself who must take the initial action by filling the order. By requesting a written confirmation of an oral order, he not only obtains an enforceable agreement against the customer, but also makes certain that he has properly recorded the specifications of the order and can present his customer with documentary proof that the goods delivered are as requested. In contrast, when a manufacturer places an order with a supplier, the latter is the party who must initiate the action and fulfill the demands of his buyer. Since the manufacturer merely awaits performance, he does not need written documents as an aid in conforming his own action to another's specifications. ${ }^{33}$

The thirty-six manufacturers who either usually or sometimes, but not always, request written confirmation of an oral purchase order ${ }^{34}$ were also asked the circumstances under which they would make such a demand. ${ }^{35}$ The criteria most frequently mentioned for distinguishing among customers in this respect were whether or not the customer submitting an oral order was known to the manufacturer, and whether or not the manufacturer lacked confidence in the customer's integrity. ${ }^{36}$ These factors may help to explain the greater tendency of the larger firms to request written follow-ups of the oral promises of both customers and suppliers. While the large manufacturer, immersed in business formality, finds it impractical to follow a flexible pattern of conduct in his dealings, the smaller businessman is more likely to have personal knowledge of his promisors which he can utilize as a basis for varying his practices. However, the relatively infrequent demand of the small businessman for writ-

33. It might appear that once the manufacturer has received his supplier's oral acknowledgment, the only additional reason for requesting a written acknowledgment would be to provide the manufacturer with a legal weapon in the event of non-performance. If this reasoning were valid, the compliance averages for requests for written acknowledgments from suppliers could be taken as a measure of the manufacturer's desire for legal security in all transactions, and only the increase in compliance averages for requests for written confirmation from customers could be ascribed to the non-legal reasons outlined in text. However, other data obtained strongly indicate that the reasons for requesting written documents from suppliers are also non-legal. See notes 63,65 infra and accompanying text.

34. See Table XIV, note 31 supra.

35. See question 5 of the Questionnaire in Appendix, page 1069 infra.

36. Of these 36 manufacturers, 24 specified their reasons for making a distinction, 4 naming two criteria: 14 would require written confirmation if the customer was not known; 8 , if confidence in the customer's integrity was lacking; 3 , if the size of the order was unusually large; 2 , if the customer used the written purchase order form himself; and 1 , if the order was for special goods. See QUEstionnaIres. 
ten follow-ups may also be an incident of his comparatively weak bargaining position, which may preclude him from freely demanding written documents from his promisors even though he would desire such documents for his own legal security. ${ }^{37}$

\section{The Extent of Reliance upon Oral Promises}

Besides ascertaining the extent to which businessmen receive and request signed documents from their customers, the Questionnaire also sought to determine to what extent manufacturers deem the receipt of such documents to be prerequisite to their own performance. Of the 77 manufacturers in the sample who always, usually, or sometimes request written confirmation of their customers' oral orders, ${ }^{38}$ only 12 make it a rule never to commence production prior to receiving such confirmation. ${ }^{39}$ Of the remaining 65 manufacturers who are willing to rely upon an initial oral order at least part of the time, 55 would do so when doing business with a customer with whom they have had only occasional prior dealings; and 33, even when doing business with a customer with whom they have had no prior dealings. But 23 of the manufacturers said that they would never act without written confirmation if the buyer did not express an urgent need for the goods, thus indicating that they prefer to wait until confirmation under normal circumstances but may make an exception if rapid commencement of production is a business necessity from the customer's viewpoint. Moreover, all but 12 of the 65 manufacturers said that they would not commence production for a customer with a poor credit rating prior to receipt of a written order. ${ }^{40}$ The findings also revealed that most of the 77 manufacturers who ever request written confirmation of oral orders will, when forced to revise an order because of inability to fill it as received,

37. But see text at note 63 infra.

38. See Table XIV, note 31 supra. The fact that a manufacturer who never requests written confirmation from his customers would commence production prior to the receipt of an expected written confirmation was felt to be insignificant. Thus, the responses of these 10 manufacturers were excluded from the analysis.

39. This information is based on the responses to question 6 of the Questionnaire. See Appendix, page 1069 infra. As expected, most (10) of these 12 manufacturers were firms which always request written confirmation of their customers' oral orders. It should be noted, however, that every other manufacturer in this latter group of 41 would commence production prior to receipt of an enforceable document from their customer. See Table XIV, note 31 supra.

40. The foregoing data are based on the answers to question 7 of the Questionnaire. See Appendix, page 1070 infra. Table XV below shows the distribution of all responses to this question. A fact not revealed by the Table is that 29 of the 65 firms (45\%) are less likely to rely on the oral orders of new than occasional customers. See QuESTIONNArREs. The figures in the Table demonstrate that reliance on the oral promises of any of the four classes of customers is not the "usual" practice of businessmen. The remarks of one medium-sized (25-100 employees) machinery manufacturer addressed to the issue of reliance explain the results found in Table XV and in text at note 39 supra: "[T]he 
commence work before the customer accepts the revision in writing. ${ }^{41}$ Only 15 of these manufacturers never begin production upon the basis of an oral acceptance of such a change in the original sales agreement, while 44 are always or usually willing to do so. ${ }^{42}$

\section{Are Exceptions to the Statute of Frauds Reflected in Practice?}

The foregoing data reveal that whether a manufacturer will rely upon his customer's oral order is dependent upon certain practical considerations, such as the extent to which he has previously done business with the customer, the customer's financial condition, and the urgency of the need for the goods. While the Statute of Frauds makes no exceptions on the basis of any of these criteria, it does specify circumstances under which a manufacturer could rely upon an oral order and still have legally recognizable rights against the customer. The Statute will not operate as a bar to enforcement if the agreement is for goods made specially to the purchaser's order, or if the value of the goods is less than a certain amount, usually $\$ 500 .^{43}$

ideal situation is, for reasons of cost and time, to be able to accomplish as much as can be done orally without a high probability of error being introduced." QuestronnaIRE.

\begin{tabular}{|l|cccc|}
\cline { 2 - 5 } \multicolumn{1}{c|}{} & \multicolumn{4}{c|}{ RESPONSE } \\
\hline NATURE of CuStoNer & Always & Usually Sometimes Never \\
\hline $\begin{array}{l}\text { One with whom the manufacturer } \\
\text { has had only occasional dealings }\end{array}$ & 7 & 13 & 35 & 10 \\
\hline $\begin{array}{l}\text { One with whom the manufacturer } \\
\text { has had no prior dealings }\end{array}$ & 3 & 7 & 23 & 32 \\
\hline One whose credit rating is poor & 1 & 1 & 10 & 53 \\
\hline $\begin{array}{l}\text { One who does not express an } \\
\text { urgent need for the goods }\end{array}$ & 1 & 8 & 33 & 23 \\
\hline
\end{tabular}

TABLE XV

Extent to which Manufacturers will Commence Production prior to Receiving Written Confirmation of Oral Orders from Various Classes of Customers

41. The Statute of Frauds imposes the same requirements for enforceability of the revised agreement as it did for the original one. See Restatement, Contracts $\$ 223$ (1932).

42. These figures are based on the answers to question 11 of the Questionnaire. See Appendix, page 1070 infra. The distribution of all responses indicating the extent tot which manufacturers rely on oral acceptances of their revisions is as follows: Always, 7; Usually, 37; About one-half the time, 4; Sometimes, 14; and Never, 15. See QUESTIONNAIRES.

43. UNIFORN SALES ACT $\$ 4(1)$, (2). The rationale given for the exclusion of contracts for goods made to the buyer's order is that such agreements are more alin to em- 


\section{Special Goods v. Stock Items}

To test whether these statutory exceptions are reflected in practice, the manufacturers were first asked whether their willingness to rely upon oral orders would be greater if special goods were ordered by the buyer. ${ }^{44}$ Of the 65 firms who at least part of the time require written confirmation of oral orders, but who are sometimes willing to commence production before receiving confirmation, $15 \%$ said that they are more likely to start production on an oral order for special goods than on one for stock items; $43 \%$ answered that they are less likely to rely upon an oral order for special goods; and $29 \%$ indicated that they make no distinction in this respect between special goods and stock items. ${ }^{45}$ Thus, the practice of over two-fifths of this group is directly contrary to that contemplated by the Statute, while less than one-fifth indicated that the statutory exception reflects business practice.

\section{Amount of the Order}

Moreover, the same 65 firms were asked whether their willingness to rely on an oral order depends upon the value of the goods requested and, if so, the amount at which they make a distinction. ${ }^{46}$ Sixty-eight per cent of these firms indicated that their reliance policy is in no way related to the amount of the order; another $6 \%$ answered that the larger the amount the more likely they are to act upon an oral order. Eighteen per cent of the firms disclosed that they make a distinction in their readiness to act on oral orders at $\$ 500$ or

ployment contracts than to contracts for the sale of goods. See Indiana Limestone Co. v. Harry Bernstein Cut Stone Co., 263 App. Div. 312, 32 N.Y.S.2d 956 (1st Dep't 1942). For discussion of a more practical justification for different treatment of this class of contracts, see text at notes $83-84$ infra.

The minimum dollar value above which the Statute becomes operative varies from $\$ 2500$, Onio Rev. Cone Ann. $\$ 1315.05$ (Page Supp. 1956), to $\$ 30$, Ark. Stat. Ann. $\S 68-1404$ (Supp. 1955) ; Mo. Rev. Stat. $\$ 432.020$ (Supp. 1956). Two states make no distinction by value. See Fla. Stat. ANv. $\S 725.02$ (Supp. 1956); Iowa Code ANN. $\S 554.4$ (Supp. 1956). The dollar amounts at which the distinction is most frequently made are $\$ 500$ and $\$ 50$.

44. See question 8 of the Questionnaire in Appendix, page 1070 infra.

45. See text at notes 38-39 supra for the source of the sample of 65 . The percentages in text represent respectively 10, 28, and 19 firms responding. In addition, 6 firms (9\%) stated that they manufactured either only stock items or only special goods, and 2 manufacturers $(3 \%)$ did not respond to the question. The remaining $1 \%$ is attributable to fractions. See QuestionNaIREs.

46. The data in this paragraph are based on the answers to the last sub-question in question 7 of the Qucstionnaire. See Appendix, page 1070 infra. If a manufacturer distinguished only between orders under $\$ 500$ and orders of a greater amount, he was considered to make a distinction at $\$ 500$ or under. Similarly, if he distinguished only between orders from $\$ 500$ to $\$ 2500$ and orders over $\$ 2500$, he was said to make a distinction at some figure over $\$ 500$. The two manufacturers who distinguished among all three classes of orders were placed in the former category in order to maximize the possibility that the statutory distinction is followed in practice. See note 49 infra and accompanying texit. 
under; and $8 \%$, at some figure over $\$ 500.47$ Since, with one exception, ${ }^{48}$ the dollar value below which the Statute of Frauds is inoperative never exceeds $\$ 500$, it is clear that the practice of no more than $18 \%$ of the firms mirrors this statutory distinction. ${ }^{49}$ Thus, the circumstances under which a businessman will rely upon an oral order bear little resemblance to the classes of oral promises excepted from the operation of the Statute of Frauds.

\section{The Attitude of the Manufacturers toward the Statute of Frauds}

Despite the fact that the manufacturers responding sometimes obtain promises from their customers and suppliers which the Statute of Frauds renders unenforceable, the manufacturers as a group do not favor an extension of the legal protection presently afforded their agreements. ${ }^{50}$ One per cent of the manufacturers believe that the law should not enforce any day-to-day business agreements; another $38 \%$ would prefer that a transaction be legally enforceable only when both parties have signed documents relating to an order; an additional $14 \%$ believe that the law should enforce precisely those agreements which are presently binding under the Statute, i.e., where both parties or the party being sued have signed memoranda of the transaction. Thus, over half of the manufacturers believe that the law should honor no more agreements than are presently upheld by the Statute of Frauds, while almost twofifths of the manufacturers would favor a change in the law making fewer agreements enforceable. ${ }^{51}$ In contrast, less than a third of the manufacturers

47. See note 46 supra. Of the 65 firms, 44 indicated they make no distinction by the amount of the order. The remaining percentages in text represent respectively 4,12 and 5 manufacturers. The explanation for the 4 firms who answered that they were more likely to act upon the receipt of a large oral order than a small one may be that the former is more apt to come from larger, and perhaps more valuable, customers.

One small (less than 25 employees) manufacturer of rubber goods bluntly compared this basis for making a distinction with that of knowledge of the customer as follows: "The distinction is made on who the customer is, on relations in the past, etc.; not on the amount of the order." QUESTIONNAIRE.

48. See Ohio Rev. Code ANN. § 1315.05 (Page Supp. 1956) ( $\$ 2500$ lower limit); UnIForar SALES ACT $\$ 4$ (statutory notes); see also note 43 supra.

49. The exact percentage is impossible to determine, for the relevant Statute of Frauds may depend upon where one of the Connecticut manufacturers obtains jurisdiction over a defaulting customer. Some states hold the Statute to be substantive. See, e.g., Smith v. Onyx Oil \& Chemical Co., $120 \mathrm{~F}$. Supp. 674, 681-82 (D. Del. 1954), vacated on other grounds, 218 F.2d 104 (3d Cir. 1955). If suit were brought in such a jurisdiction, the critical amount would probably be not $\$ 500$ but the $\$ 100$ figure found in the Connecticut Statute of Frauds, Conn. Gen. Stat. $\$ 8294$ (Supp. 1955). See Restatement, Conflicts $\$ 334$, comment b (1934). On the other hand, those jurisdictions which characterize the Statute as procedural would apply the lex fori. See, e.g., Porter v. Reid, 79 F. Supp. 898 (D. Mass. 1948) ; Fimian v. Guy F. Atkinson Co., 209 Ga. 113, 70 S.E.2d 762 (1952).

50. The data in this paragraph are based on the responses to question 17 of the Questionnaire. See Appendix, page 1071 infra.

51. See note 1 supra and accompanying text for the agreements presently upheld by the Statute of Frauds. 
would prefer to have more agreements enforceable than are honored under existing law : 18\% would favor the extension of legal protection to a party who had performed in reliance upon an oral order, ${ }^{52}$ and $12 \%$ would have all agreements enforceable, even in the absence of signed documents or part performance. The remaining $17 \%$ of the manufacturers would have the law honor some presently unenforceable agreements, but would at the same time withdraw existing legal protection surrounding other classes of promises. Thus, $3 \%$ of the manufacturers would enforce an agreement only if the suing party, relying upon either a written or oral promise, had already performed, and $14 \%$ would enforce only such an agreement and one marked by the signed documents of both contracting parties. ${ }^{53}$ The only kind of agreement which a majority of the manufacturers believes should be enforced, then, is one where both parties have signed documents relating to the transaction, $96 \%$ favoring the legal recognition of such an agreement. ${ }^{54}$

52. It should be noted that the equitable doctrine of part performance applies exclusively to oral agreements for the sale of an interest in land. Ackerman-Beardsley-Bennet, Inc. v. Baker, 19 Conn. Supp. 205, 111 A.2d 17 (C.P. 1954); 2 Wirliston, ConTRACTS $\$ 533$ (rev. ed. 1936); compare RESTATEMENT, ConTRACTs $\$ 1.97$ (1932), with UNIFORM SALES ACT $\$ 4(1)$, (3).

53. Eighty-one manufacturers responded to this question. The percentages in text at notes 51-53 supra, represent respectively the following numbers of manufacturers: 1,31 , $11,15,10$ and 13 ( 2 and 11 ).

Table XVI below shows the responses to this question by the size of the manufacturer answering. The meaningful figures are fairly consistent for the four size groups, except that the smallest manufacturers (group I) appear to favor the most restrictive role of the law.

\begin{tabular}{|c|c|c|c|c|c|}
\hline & \multicolumn{4}{|c|}{ SIZE Group } & \\
\hline RESPONSE & $\bar{I}$ & $\overline{I I}$ & III & IV & Total \\
\hline $\begin{array}{l}\text { Desire Fewer Agree- } \\
\text { ments Enforceable }\end{array}$ & 11 & 12 & 5 & 4 & 32 \\
\hline $\begin{array}{l}\text { Desire More Agree- } \\
\text { ments Enforceable }\end{array}$ & 4 & 11 & 7 & 3 & 25 \\
\hline $\begin{array}{l}\text { Desire the same Agree- } \\
\text { ments Enforceable }\end{array}$ & 2 & 3 & 4 & 2 & 11 \\
\hline Indeterminate* & 2 & 6 & 5 & 0 & 13 \\
\hline Total Responses & 19 & 32 & 21 & 9 & 81 \\
\hline
\end{tabular}

* See text at notes $52-53$ supra.

\section{TABLE XVI}

Agreements Desired Enforceable by Different

Size Manufacturers in Relation to Those

Presently Binding under the Statute of Frauds

54. This percentage represents 78 of the 81 manufacturers responding. The legal enforceability of two other classes of agreements received almost majority approval: $47 \%$ 


\section{The Influence of the Nature of the Promises Received}

The reluctance of the manufacturers as a group to extend the present scope of legal protection afforded business agreements is especially significant, since most of the manufacturers who indicated that they do not favor such an extension obtain promises from their customers or suppliers which are not enforceable under existing law. Of the 43 manufacturers who feel that the law should never enforce an oral promise, 34 at least part of the time receive oral promises unconfirmed in writing in the course of their buying or selling practices ${ }^{55}$ Thus, these manufacturers favor a law which presently affords them no legal recourse against a supplier who does not deliver goods after orally acknowledging an order, ${ }^{56}$ or against a customer who refuses to accept goods delivered by the manufacturer in reliance upon an oral order. ${ }^{57}$ Of the 28 manufacturers who would enforce an oral order, but only if accompanied by the promisee's performance, 27 at least part of the time receive oral promises unconfirmed in writing from their suppliers or customers. ${ }^{58}$ Accordingly, these manufacturers do not believe that the oral promises of the parties with whom they deal should be enforced, except in those instances where they have commenced production in reliance upon a customer's oral order, or have paid a supplier in advance of delivery.

Moreover, 17 manufacturers would restrict the scope of the law in such a way that some of the presently binding promises of their customers would no longer be enforceable. Fifteen of the manufacturers who desire legal enforceability of agreements signed by both parties, but not of those signed only by the party to be charged, at least part of the time do not supply their customers with written acknowledgments of written orders..$^{59}$ Eleven of these 15 manufacturers would enforce a written order only if followed by a written acknowledgment, while the remaining four would also enforce a written order not acknowledged in writing if the seller had performed in reliance. Thus, the former group would deny themselves the right which they presently enjoy to sue a customer upon any written order acknowledged orally or by shipment. ${ }^{\text {an }}$ The latter group believes that the law is erroneous in granting their present right to collect damages for the cancellation of a written order acknowledged

(38) of the 81 manufacturers would enforce a promise, oral or written, if the suing party had performed; $44 \%$ ( 36 firms) would enforce an agreement against a party who had signed a memorandum relating to the transaction even if the suing party had not. However, only $12 \%$ (10) of the manufacturers responding would have all agreements enforceable. See text at notes 50-53 supra.

55. These data are based on a cross-analysis of the responses to question 17 , see note 53 supra and accompanying text, and questions $3,4,5,15$ and 16 of the Questionnairc. See Appendix, pages 1069, 1071 infra.

56. See, e.g., Carmichael v. Stone, 243 Iowa 904, 54 N.W.2d 454 (1952).

57. See, e.g., Marilyn Shoe Co. v. Martin's Shoe Store, Inc., 253 S.W.2d 18 (Ky. 1952).

58. See note 55 supra.

59. The data in this paragraph are based on a cross-analysis of the responses to questions 10 and 17 of the Questionnaire. See Appendix, pages 1070-71 infra.

60. See notes 1, 9 supra and accompanying text. 
orally but not yet resulting in performance. ${ }^{61}$ In addition to these $15 \mathrm{manu}$ facturers, the two manufacturers who would only enforce a promise if the promisee had already performed often receive and acknowledge written orders which under existing law would be binding on the customer prior to the manufacturer's performance.

\section{The Influence of the Practice Followed After Breach}

The unwillingness of manufacturers to have the law enforce oral promises and even some of the written promises which are presently binding indicates that they favor restricted intervention of the law into the field of ordinary business dealings. This laissez faire attitude toward legal sanctions is explained by the action which manufacturers take in the event that a customer reneges on his commitments. ${ }^{62}$ Only $10 \%$ of the manufacturers responding to the Questionnaire ever make it their practice to sue upon cancellation of an order, ${ }^{03}$ and all the firms comprising the $10 \%$ usually follow a different practice. Of the total number of manufacturers, 69 , who indicated that they are most likely to pursue a particular course of action against a defaulting customer, $30 \%$ always or usually take no action at all, $61 \%$ settle for expenses incurred, and $9 \%$ insist upon a settlement of expenses plus lost profits. ${ }^{64}$ Since

61. See note 1 supra and accompanying text.

62. The data in this paragraph are based on the responses to question 12 of the Questionnair. See Appendix, page 1070 infra.

63. The group of 8 manufacturers comprising the $10 \%$ is distinguished only by its complete heterogeneity. It represents seven industry groups and all four sizes as follows: R, I; W, I; B, II ; I, II; MI, II; A, III; B, III ; and E, IV. See QUestionnaIres.

64. Seventy-eight firms responded to this question. However, the answers of 9 firms did not reveal that any one course of conduct was more likely to be followed than one or more of the other three. See Questionnaires.

The distribution of responses for all 78 manufacturers is given by Table XVII below. The average manufacturer settles for expenses incurred more than one-half of the time, sometimes takes no action, seldom settles for expenses plus lost profits, and only rarely sues. A breakdown by size groups shows remarkable consistency of practice for all sizes, and therefore these figures are not reprinted here. See QuestronnaIREs.

\begin{tabular}{|c|c|c|c|c|}
\hline & \multicolumn{4}{|c|}{ RESPONSE } \\
\hline UPON BREACH & Always & Usually & Sometimes & Never \\
\hline Sue & 0 & 0 & 8 & 70 \\
\hline $\begin{array}{l}\text { Settle for } \\
\text { Expenses Incurred }\end{array}$ & 15 & 27 & 14 & 22 \\
\hline $\begin{array}{l}\text { Settle for Expenses } \\
\text { Plus Lost Profits }\end{array}$ & 0 & 6 & 21 & 51 \\
\hline Take No Action & 7 & 14 & 15 & 42 \\
\hline
\end{tabular}

TABLE XVII

Course of Conduct Followed by 78 Manufacturers upon Cancellation of an Order by a Customer after Production has Commenced 
almost all of the manufacturers never resort to litigation as a method of resolving their disputes, and since all but a handful usually either seek no compensation at all or are satisfied to settle for less than their legal right of recovery, the legal enforceability of the promises of the parties with whom they deal apparently means little to them. ${ }^{65}$ Accordingly, if oral promises were made enforceable, the additional legal rights bestowed upon a manufacturer who receives such promises would most likely be unexercised; ${ }^{60}$ but, if the status quo is retained, the same manufacturer gains from the fact that his suppliers and customers are barred from suing him on his own oral promises. Moreover, the manufacturer is protected from possible suits predicated on alleged oral promises which he has never made.

The same reasoning would explain the desire of the majority of manufacturers to terminate the legal enforceability of a class of promises presently binding-where only the party being sued has signed documents relating to the agreement. If the manufacturer's promisor is the party who alone has signed a document, the law will not be utilized as an offensive weapon by the manufacturer in the event of a breach, even though he has legal rights which the courts would recognize. And in the situation where the manufacturer is the only party who has signed a memorandum of the agreement, he will not want the party with whom he deals to have access to the courts, especially since he himself would have no legal rights on the same agreement in the case of a breach by his promisor.

\section{Should the Statute of Frauds Be Retained?}

The complex of data concerning the action which manufacturers take in the event a customer cancels his order throws new light on one important aspect of the controversy involving the Statute of Frauds-whether it fosters or prevents fraud. ${ }^{67}$ When a party to a business transaction breaches his agreement, his resort to the Statute to escape his duty of providing compensation might be considered fraud. However, consideration of actual business practice in such circumstances indicates that even where a defendant has admittedly failed to live up to the terms of his promise, his subsequent reliance on the Statute as a defense may be justifiable. Thus, if the litigating parties have had exten-

65. The usual measure of damages for breach of contract is expenses incurred plus lost profits. Restatenent, CoNtracts \& 329, comment b (1932).

It might be thought that the enforceability of a customer's promise dictates the amount which a manufacturer will receive from his customer upon the latter's cancellation of an order. Cross-analysis of the data previously reported shows this not to be so. While 70 manufacturers usually or always obtain enforceable promises from their customers, see note 14 supra, only 6 of the 70 usually or always insist on their legal measure of recovery.

66. Numerous comments were addressed to the question of whether the manufacturer would sue upon breach. Perhaps the manufacturer's adverse attitude towards litigation is best expressed in the words of one medium-size (100-500) fabricated metals manufacturer: "So far, we have been quite successful in avoiding law suits, and believe other methods of adjustment are much more effective-and leave a better taste." QuestronNAIRE.

67. See notes 1-4 supra and accompanying text. 
sive prior dealings, and the plaintiff's known practice is to take no action upon default by his promisors, a forcible argument can be made that insistence on legal rights in this case is in violation of the defendant's legitimate expectations. And the same argument would apply if the plaintiff's known practice is to settle for expenses incurred only, and the defendant is willing to afford him this measure of settlement. ${ }^{68}$ Because of the role of past practices, it is clear that no generalization can be made as to whether the existence of the Statute tends to facilitate or prohibit unfair conduct. Therefore, in evaluating the desirability of the Statute for the modern business world, factors other than the fulfillment or non-fulfillment of its original purpose of preventing fraud must be considered.

The formal requirements for legal enforceability of business agreements should accord with the prevailing practice and attitude of the business community. ${ }^{09}$ It may be contended that gearing enforceability to the observance of formalities in business transactions, despite a contrary practice and attitude, is justified, since the law should be utilized to encourage a manner of business dealing which, though not presently followed, the legislature deems preferable. Yet, if the businessmen who participate in these transactions choose, in the exercise of their business judgment, to follow a different pattern of dealing with each other, the law applicable to private disputes should not become an instrument of forcing compliance with the conflicting opinion of another segment of the community regarding the manner in which business should be conducted. ${ }^{70}$ Accordingly, if business practice uniformly complies with the requirements of the Statute of Frauds, and if businessmen unanimously agree that the Statute should be retained, any argument for repeal of the Statute as

68. The fundamental purpose of the law of contracts is usually said to be protection of those expectations which have been aroused by the agreement of the parties. See 1 Corbin, Contracts $\$ 1$ (1950); Grisarore, Principles of the Law of Contracts 1 (1947). An established pattern of settling would clearly seem to give rise to an expectation as to what will occur upon breach.

69. See, $c . g$. ., Cardozo, The Nature of the Judictal Process 61-64 (1921) (approving the expansion of law to meet the wants of trade through adopting trade customs as the norm of the law) ; 1 CoRBIn, Contracts $\$ 1$ (1950) (law, to be just, must be an expression of normal conduct); Corbin, The Uniform Commercial Code-Sales; Should It Be Enacted?, 59 Y YLE L.J. 821, 822-24 (1950) (depicting the development of commercial law since the time of Lord Mansfield as necessarily an accommodation to business usages and customs); Stephen \& Pollock, Section Seventeen of the Statute of Frands, 1 L.Q. REv. 1, 6-7 (1885).

70. Freedom of contract, a basic principle of Anglo-American contract law, is frequently limited by the law in the name of overriding public policy. KessLeR \& SHARP, Contracts 36-38 (1953); Willis, Contracts: A Law of Rights, Powers, Privileges and Immunities, 27 IND. L.J. 182, 195-96 (1952). Such limitations may be justified when they attempt to discourage the making of contracts which are illegal, immoral, or otherwise in conflict with the interests of the larger community. However, the only interests protected by requiring compliance with the formalities of contract law are those of the contracting parties themselves. Thus, the formalities required for legal enforceability of business agreements should be those which reflect the standards of the group affected-the business community engaged in contracting activities. 
it affects business transactions is effectively countered. On the other hand, if the business community ignores the requirements of the Statute in its dayto-day dealings and disapproves of the legal disabilities which it creates, the present worth of the Statute may be severely questioned. Since the responses to the Questionnaire indicate the extent to which business promises actually satisfy the demands of the Statute, as well as the attitude of businessmen toward retention of the legislation, they are valuable data in evaluating the desirability of the Statute for the modern business world.

Business practice usually complies with the requirements of the Statute of Frauds. ${ }^{71}$ The average manufacturer ordinarily reduces his own commitments to writing and receives written promises from the parties with whom he deals. But manufacturers' transactions probably are characterized by signed memoranda because the parties deem it sound business practice to have written records, and not because they are concerned with the legal enforceability of their promisors' obligations under the Statute of Frauds. This conclusion is bolstered by the findings that 1) $90 \%$ of the manufacturers never turn to the courts in the event of a breach ${ }^{72} 2$ ) the manufacturers' practice of obtaining written records is not changed for orders of special goods or for orders below the value of $\$ 500$, even though the customer can be legally held to such orders in the absence of a signed memorandum $;^{73} 3$ ) even those manufacturers who request written memoranda from their customers are frequently willing to commence production on the basis of an unenforceable oral order, thus sacrificing the certainty of a legally binding promise for business expediency ${ }^{74}$ 4) most manufacturers are willing to rely on an oral acceptance of their revision of an order, even though the customer is not legally obligated to accept goods conforming to the revised terms $;^{\mathbf{7 5}}$ and 5) the manufacturer is frequently satisfied with an oral acknowledgment from a supplier, and does not request a written acknowledgment to ensure the existence of legal rights in case the supplier fails to deliver. ${ }^{76}$

Thus, it seems proper to conclude that business practice would not be modified if the Statute of Frauds were repealed and oral promises were made legally binding. The businessman would still want written records irrespective of their legal value; for the reduction of commitments and agreements to writing contributes to a smoother working business organization and eliminates the uncertainties and confusion which may accompany agreements involving only the spoken word. Accordingly, the only effect which repeal of the Statute of Frauds would have for the business community would be to allow an additional, and limited, class of promisees access to the courts in the event of a breach.

71. See notes 11-16 supra and accompanying text.

72. See note 63 supra and accompanying text.

73. See notes 43-49 supra and accompanying text.

74. See text at note 39 supra; note 40 supra.

75. See notes 41-42 supra and accompanying text.

76. See notes 29-30 supra and accompanying text. 
The majority of businessmen answering the Questionnaire does not believe that this class of promisees should have legal rights, especially when the potential plaintiff has not performed in reliance upon the oral promise. Eighty-eight per cent of the manufacturers expressed the opinion that the law should not enforce an oral promise if the suing party has not performed. ${ }^{77}$ The explanation for this aversion to the intervention of the law may be found in the nature of the business transaction which is marked by an oral promise. Since businessmen usually give and obtain promises evidenced by signed memoranda, a transaction not following this pattern obviously constitutes an exception to standard business practice. And the fact that many manufacturers will not insist upon written confirmation of an oral order if the customer is known to them, and known to be reliable, ${ }^{78}$ indicates that the promisee will make this exception, if at all, when dealing on a personal, informal basis with a party with whom he has regularly carried on business. This conclusion is also supported by the greater prevalence of oral promises in the transactions of small manufacturers than in those of large ones, ${ }^{70}$ for the opportunities of the small manufacturer to do business under such conditions that the contracting parties will gain personal lnowledge of each other are of course far greater. Businessmen who have dealt informally for a considerable period of time may not feel the need to possess documents signed by the obligated party or to have the latter's oral promise legally enforceable. And if the parties do want the law to supervise their transactions, it seems fair to assume that they will reduce their respective commitments to writing. For only $12 \%$ of the manufacturers never require a written confirmation of their customer's oral orders, ${ }^{80}$ thus indicating that an overwhelming majority of the manufacturers will request a signed memorandum at least in those cases where they desire legal protection. Under these circumstances, it seems doubtful whether any interest would be served by making oral promises legally enforceable, especially when there has been no action in reliance. The parties do not want such a law, and there is no reason why it should be forced upon them.

If, however, a businessman has actually relied upon an oral order by commencing production, other factors may come into play. While only $12 \%$ of the manufacturers responding want an oral promise legally binding if the suing party has not acted in reliance, almost half of the manufacturers $(47 \%)$ believe that the law should enforce an oral promise accompanied by performance. ${ }^{81}$ The greater enthusiasm of the manufacturers for having the latter class of promises enforceable, as well as the unwillingness of $53 \%$ of the manufacturers to have the law enforce any oral promise, may be better understood by considering the situations in which an oral order may be cancelled after production has begun. Such a cancellation might be made by a customer who is dealing

77. See text at notes 50-53 sipra.

78. See note 36 supra and accompanying text.

79. See notes $19-23$ supra and accompanying text.

80. See Table XIV, note 31 supra.

81. See note 54 supra. 
on a personal, informal basis with the manufacturer, the parties not having insisted upon any signed memoranda relating to the transaction. Under these circumstances, a strong argument can be made that the manufacturer should have no legal rights notwithstanding his reliance upon the oral order, since the parties, by waiving the written documents which usually accompany business transactions, have manifested an intention that their dealings be immune from legal regulation. However, such a result may be harsh for the manufacturer..$^{82}$ It is arguable that, to achieve an equitable balance, the manufacturer should be permitted to recover reliance damages but not expectation damages. Thus, he should not be entitled to any compensation for lost profits but should be allowed to recoup any out-of-pocket expenditure which he has made in reliance upon the order and which is now wasted. Since the manufacturer has chosen to rely essentially upon non-legal sanctions, the damages recoverable from a recalcitrant customer should not exceed that sum which he had a right to expect under the prevailing business practice of settling for expenses alone upon cancellation of an order.

In order to enable the manufacturer to recover such an amount, it would not be necessary to amend the Statute of Frauds. For the Statute will not bar enforcement of a customer's oral promise if the requested goods are to be made specially to the buyer's order. ${ }^{83}$ And the situation in which the manufacturer will incur an out-of-pocket expense which cannot be otherwise recouped will be the case where the customer cancels an oral order for special goods the production of which has already commenced. If the cancelled order is for stock items, the manufacturer will ordinarily incur no wasted expenditure, since he can sell the goods he has started to produce to another buyer. However, while the "special goods" exception to the Statute of Frauds serves a commendable function in this context, it goes too far in automatically allowing the manufacturer who is dealing informally with his customer to obtain lost profits as well as expenses in the event that an oral order for special goods is cancelled. The ideal solution would disallow recovery of lost profits where the plaintiff's custom was to rely solely upon the oral promise of the buyer.

On the other hand, situations may arise in which a businessman, though dealing on an impersonal basis and in accordance with the usual practices of the business community, will be faced with the task of enforcing an oral promise on which he has relied. Most manufacturers feel it generally sound

82. The extent to which the ground of "unconscionable injury" may presently be utilized to avoid the bar of the Statute of Frauds in an ordinary business transaction is not clear from the case law. Compare Holton v. Reed, 193 F.2d 390 (10th Cir. 1951), with Booth v. A. Levy \& J. Zentner Co., 21 Cal. App. 427, 131 Pac. 1062 (1913). Where the transaction is not in the ordinary course of business, courts have been more prone to rely on such equitable considerations. See Brewood v. Cook, 207 F.2d 439 (D.C. Cir. 1953); Berkey v. Halm, 101 Cal. App. 2d 62, 224 P.2d 885 (1950).

83. See UnIForar SALES AcT $\$ 4(2)$. The "special goods" exception can be utilized only if the goods are not salable to another buyer in the ordinary course of the seller's business. Ibid. 
business practice to commence production solely on the basis of an oral purchase order, even though a forthcoming confirmation with the customer's signature is expected or required..$^{84}$ If a manufacturer follows this practice, and the customer cancels an oral order prior to sending his signed confirmation, the manufacturer's legal rights will depend upon the enforceability of an oral promise upon which the promisee, by performing, has relied. Unlike those transactions in which the parties have chosen to deal with each other on an informal basis, the manufacturer in this situation followed prevailing business practice and expected to obtain a legally enforceable promise from his customer. If the law does not enforce the customer's oral commitment under these circumstances, it forces businessmen to make a choice between enjoying a legally secure position and adhering to a method of dealing which the business community usually follows and considers sound practice. But the law should not force a party to abandon such practice as the price of obtaining legal protection. Therefore, where a seller performs in reliance upon an oral order for goods, and it can be shown, either by reference to the past dealings of the parties ${ }^{85}$ or by the parties' actions in the case in question, that the seller reasonably expected a signed memorandum to be forthcoming, the law should enforce the oral promise as though it were in writing.

In addition to indicating whether business practices and desires pointed toward repeal of all or part of the Statute of Frauds, the responses also raised the issue whether the Statute should be amended to make some promises unenforceable which are legally binding under present law. Fifty-six per cent of the manufacturers feel that a promise evidenced by a signed memorandum which has not evoked performance should not be enforceable unless the promisee has also signed documents relating to the transaction. Such a case could arise where a manufacturer sued a customer for cancelling a written order which had been acknowledged orally, or where a manufacturer who acknowledged an oral order in writing was sued by his customer for nondelivery of the goods. However, since $44 \%$ of the manufacturers would approve the victory which present law affords the plaintiff in these cases, it cannot be said that the desires of the group as a whole would be served by tightening the Statute. If actual business practices are considered, the Questionnaire data reveal that only 1 of 87 manufacturers usually acknowledges written orders orally. 87 The infrequency of such oral acknowledgments provides some basis for arguing that the Statute of Frauds should be amended to deny recovery to the manufacturer-promisee who departs from the well-established business norm of acknowledging written orders in writing. It may be contended that

84. See note 39 supra and accompanying text.

85. Past practices of the parties may not be decisive of their rights under existing law. See, e.g., Ackerman-Beardsley-Bennett, Inc. v. Baker, 19 Conn. Supp. 205, 111. A.2d 17 (C.P. 1954); Continental Nut Co. v. Slate, 97 Cal. App. 2d 264, 217 P.2d 673 (1950).

S6. See note 54 supra.

87. These data are based on the responses to question 10 of the Questionnaire. See Appendix, page 1070 infra. 
such an amendment cannot be conceptually rationalized as an attempt to prevent fraud, since the promisor will have signed a written memorandum of the promise upon which he is being sued. However, while this memorandum would establish that the order had been made, fraud would still be possible on the question whether the order was ever orally accepted prior to cancellation and thus gave rise to a contract. In the case of written acknowledgments of oral orders, the responses to the Questionnaire reveal that $64 \%$ of the manufacturers usually follow this practice. ${ }^{88}$ In view of the frequency of this pattern of dealing, the Statute of Frauds should not be amended to eliminate the rights which customers receiving written acknowledgments presently enjoy.

88. This percentage represents 54 of the $\$ 4$ manufacturers who responded to question 9 of the Questionnaire. See Appendix, page 1070 infra. 


\section{APPENDIX}

\section{QUESTIONNAIRE}

For each question, please check the answer or answers which best describe the practice and experience of your firm or that represent your best estimate of the course you would follow under the conditions suggested. Please disregard transactions with controlled subsidiaries of your firm, and, if your firm is a controlled subsidiary, glease disregard transactions with your parent company. Please feel free to make any additional comments on the back of the last page.

1. Your firm employs:

Less than 25 persons

25 to 100 persons

100 to 500 persons

More than 500 persons

\section{Selling Practices}

2. Orders for your product are obtained by :

Solicitation by salesmen

Competitive bids

Unsolicited inquiries

Other (please specify)

Orders from catalogs

3. If the initial order is taken by a salesman, will he transmit it:

Always Usually Sometimes Never

By telephone or other word of mouth

By telegram

By mail with customer's signature or stamp

By mail without customer's signature or stamp

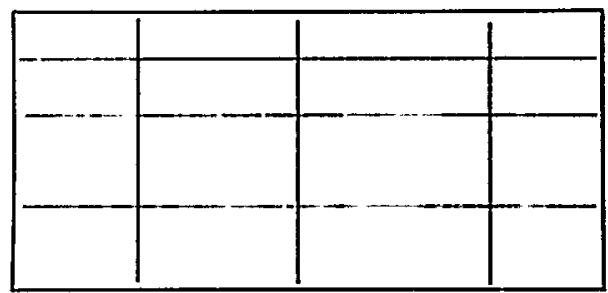

4. If the initial order comes directly from your purchaser to your office, will it be:

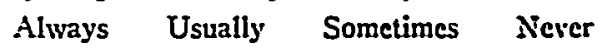

By telephone or other word of mouth

By telegram

By mail

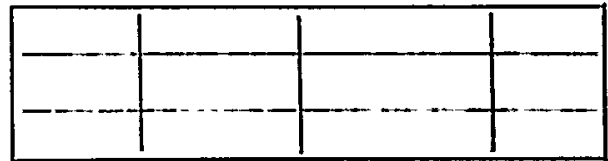

5. If the initial order is not in writing or is not signed by your customer, do you request written confirmation of the order?
Always
Usually
Sometimes
Never
If Usually or Sometimes, when?

6. When you receive an order by word of mouth, will you ever begin production before you or your salesman receives a written confirmation of that order from your purchaser? Yes No 
7. If your answer to the previous question was yes, do you follow this practice when dealing with a customer:

With whom you have had only occasional dealings

With whom you have had no prior dealings

Whose credit rating is poor

Who does not express an urgent need for the goods

Who has placed an order for: under $\$ 500$

$\$ 500$ to $\$ 2500$

over $\$ 2500$

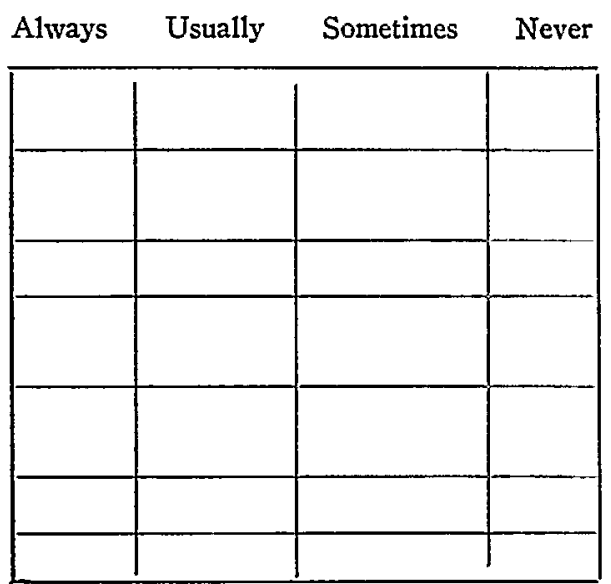

8. If your answer to question 6 was yes, is it more usual to begin production without a written order on stock items than on goods made to special order?

More usual Less usual No difference

9. How do you acknowledge or confirm oral (including telephone) orders: Always Usually Sometimes Never

By personal visit

By telephone only

By mail

By telegram

By shipment only

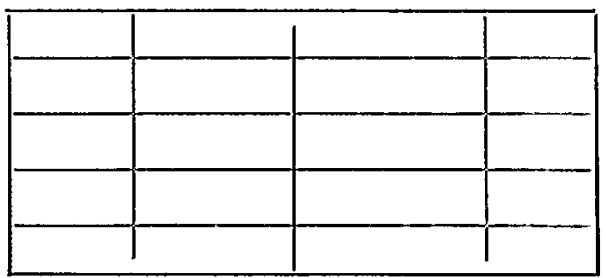

10. How do you acknowledge or confirm written orders :

By personal visit

By telephone only

By mail

By telegram

By shipmènt only Always Usually Sometimes Never

11. If, for any reason, you cannot fill a written order exactly as received, would you start work on the revised order or make shipment:

\begin{tabular}{|l|l|l|l|}
\hline & & & \\
\hline & & & \\
\hline & & & \\
\hline & & & \\
\hline & & & \\
\hline
\end{tabular}

Always Usually Sometimes Never

Before notifying the customer of the change

When oral agreement is reached on the change

Upon receipt of a written confirmation

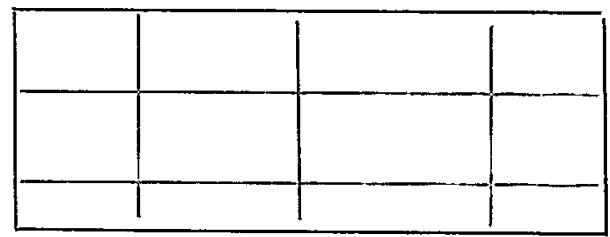


12. If a purchaser cancels an order after you have commenced production, is it your practice to:

Always Usually Sometimes Never

Sue

Settle for expenses incurred

Settle for expenses incurred plus lost profits

Take no action

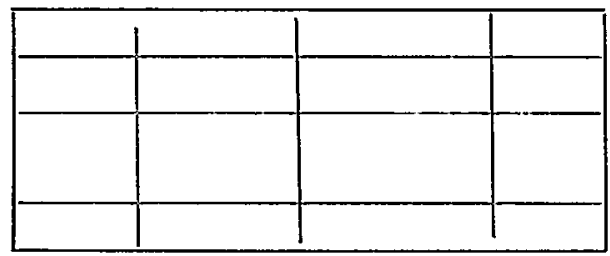

\section{Buying Practices}

13. When you initially place an order for materials or supplies with a supplier, do you communicate this order:

Always Usually Sometimes Never

By telephone

By telegram

By mail

By personal visit

\begin{tabular}{|l|l|l|l|}
\hline & & & \\
\hline & & & \\
\hline & & & \\
\hline & & & \\
\hline
\end{tabular}

14. Do you later confirm your telephone or other oral orders (if any) in writing? Always Usually Sometimes Never

15. When you have placed an order with one of your suppliers, how will he confirm the order?

By telephone

By telegram

By shipment only

By mail

Always Usually Sometimes Never

16. If the supplier's initial confirmation of the order is not in writing, would you request written confirmation?

Always Usually Sometimes Never

17. Please check as many of the following transactions as you think the law should enforce:

Where both parties have signed documents relating to an order

Where only the party being sued has signed documents relating to an order

Where neither party has signed documents relating to an order, but the suing party has performed

Where neither party has signed documents relating to an order, and the suing party has not performed 